Jurnal Farmamedika Vol. 1, No. 1 Juni 2016

\title{
EVALUASI KEJADIAN INTERAKSI OBAT PADA PASIEN RAWAT INAP GERIATRI PENDERITA GAGAL JANTUNG
}

\author{
Siti Mariam ${ }^{1}$ \\ ${ }^{1}$ Program Studi S1 Farmasi Sekolah Tinggi Teknologi Industri dan Farmasi Bogor
}

\begin{abstract}
ABSTRAK
Suatu interaksi terjadi ketika efek suatu obat diubah oleh kehadiran obat lain, obat herbal, makanan, minuman atau agen kimia lainnya dalam lingkungannya. Interaksi obat dianggap penting secara klinik bila berakibat meningkatkan toksisitas dan atau mengurangi efektivitas obat yang berinteraksi terutama bila menyangkut obat dengan batas keamanan yang sempit (indeks terapi yang rendah).Kejadian interaksi dapat terjadi pada pasien yang menggunakan dua atau lebih obat.Penggunaan obat yang banyak, sering terjadi pada pasien geriatri yang mengidap penyakit degeneratif seperti hipertensi, diabetes melitus, dislipidemia, osteoartritis, dan penyakit kardiovaskular.Penelitian dilakukan secara retrosfektif menggunakan data rekam medik (Medical Record/MR) pasien geriatri penderita gagal jantung yang dirawat inap di Rumah Sakit Betha Medika Sukabumi periode bulan Maret-April 2016.Diperoleh 70 pasien, 46\% laki-laki dan 54\% perempuan.Penyakit penyerta tertinggi, dari 10 penyakit penyerta dengan pasien terbanyak adalah Penyakit Jantung Hipertensi $(\mathrm{PJH})$. Interaksi obat terjadi antara : spironolakton, digoksin, amlodipin, bisoprolol dengan obat-obat lain golongan obat gagal jantung maupun obat penyakit penyerta dengan jumlah kejadian interaksi berbeda beda.
\end{abstract}

Kata kunci : gagal jantung, geriatri, interaksi obat.

\begin{abstract}
An interaction occurs when the effects of a drug changed by the presence of other drugs, herbal medicine, food, drinks or other chemical agents in the environment. Drug interactions considered clinically important when the resulting increase or decrease the toxicity and effectiveness of the drugs that interact, especially when it comes to drugs with narrow safety margin (low terapheutic window). Genesis interactions may occur in patients taking two or more drugs. Interaction incident may occur in patients taking two or more drugs. The use of many drugs that often occur in geriatric patients, who suffer from degenerative diseases such as hypertension, diabetes mellitus, dyslipidemia, osteoarthritis and cardiovascular disease. Research conducted retrosfektif using medical records (MR) geriatric patients suffering from heart failure who are hospitalized in the Betha Medika Hospital in Sukabumi period March-April 2016. Retrieved 70 patients, 45\% male and $54 \%$ female. Morbidities highest of 10 comorbidities with most patients is Hypertension Heart Disease (PJH). Drud interaction occur between: spironolactone, digoxin, amlodipine, bisoprolol with other drugs medicine drug classes heart failure and comorbid disease drug interactions with the number of events is different.
\end{abstract}

\section{Keyword : heart failure, geriatric, drug interaction}

\section{PENDAHULUAN}

Suatu interaksi terjadi ketika efek suatu obat diubah oleh kehadiran obat lain, obat herbal, makanan, minuman atau agen kimia lainnya dalam lingkungannya [1]. Interaksi obat merupakan satu dari delapan kategori masalah terkait obat (drug-related problem) yang diidentifikasi sebagai kejadian atau keadaan terapi obat yang dapat mempengaruhi outcome klinis pasien.Interaksi obat dianggap penting secara klinik bila berakibat meningkatkan toksisitas dan atau mengurangi efektivitas obat yang berinteraksi terutama bila menyangkut obat dengan batas keamanan yang sempit (indeks terapi yang rendah) [2].Interaksi bisa bersifat potensiasi atau antagonis efek satu obat 
oleh obat lainnya, atau adakalanya beberapa efek lainnya [3].

Interaksi obat berdasarkan mekanismenya dibedakan menjadi 3 (tiga) macam, yaitu incompatibilitas, interaksi farmakokinetik dan interaksi farmakodinamik (1). Berdasarkan level kejadiannya , interaksi obat terdiri dari established (sangat mantap terjadi), probable (interaksi obat bias terjadi), suspected (interaksi obat diduga terjadi), possible (interaksi obat mungkin terjadi, belum pasti terjadi), serta unlikely (interaksi obat tidak terjadi). Sedangkan berdasarkan keparahannya, interaksi obat dapat diklasifikasikan menjadi tiga yaitu mayor (dapat menyebabkan kematian), moderat (sedang), dan minor [4].

Insidens interaksi obat yang penting dalam klinik sukar diperkirakan karena (1) dokumentasinya masih sangat jarang; (2) seringkali lolos dari pengamatan karena kurangnya pengetahuan dokter akan mekanisme dan kemungkinan terjadinya interaksi obat sehingga interaksi obat berupa peningkatan toksisitas seringkali dianggap sebagai reaksi idiosinkrasi terhadap salah satu obat sedangkan interaksi berupa penurunan efektivitas seringkali diduga akibat bertambahnya keparahan penyakit; selain itu terlalu banyak obat yang saling berinteraksi sehingga sulit untuk diingat; dan (3) kejadian atau keparahan interaksi dipengaruhi oleh variasi individual (populasi tertentu lebih peka misalnya penderita lanjut usia atau yang berpenyakit parah, adanya perbedaan kapasitas metabolisme antar individu), penyakit tertentu (terutama gagal ginjal atau penyakit hati yang parah), dan faktor-faktor lain (dosis besar, obat ditelan bersama, pemberian kronik) [1].

Penderita usia lanjut atau geriatri memiliki karakteristik khusus, yaitu umumnya telah terjadi berbagai penyakit kronis, fungsi organ yang menurun, terutama menurunnya fungsi ginjal dan hepar, dapat menyebabkan perubahan proses farmakodinamik dan farmakokinetik obat tersebut [5]. Secara global penyakit tidak menular penyebab kematian nomor satu setiap tahunnya adalah penyakit kardiovaskuler. Penyakit kardiovaskuler adalah penyakit yang disebabkan gangguan fungsi jantung dan pembuluh darah, seperti: Penyakit Jantung Koroner, Penyakit Gagal Jantung atau Payah Jantung, Hipertensi dan Stroke.

Pasien gagal jantung biasanya menderita penyakit penyerta yang lain sehingga membutuhkan berbagai macam obat dalam terapinya. Semakin banyak obat yang dikonsumsi seringkali dikaitkan dengan potensi yang lebih besar untuk terjadinya interaksi obat dan efek samping.Menurut beberapa peneliti, insiden reaksi obat yang tidak diinginkan (adverse drug reaction / ADR) meningkat sebanding dengan jumlah obat yang digunakan oleh individu [6].

Populasi lanjut usia memiliki risiko terbesar karena adanya perubahan fisiologis yang terjadi dengan proses penuaan. Penelitian ini bertujuan untuk mengevaluasi kejadian interaksi obat yang diberikan pada pasien rawat inap geriatrik yang menderita penyakit gagal jantung.

\section{METODE PENELITIAN}

Desain penelitian yang digunakan adalah rancangan studi potong lintang (Cross Sectional).Pengambilan data dilakukan secara retrospektif terhadap data sekunder berupa rekam medik (RM) pasien dari bulan Maret sampai April 2016. Populasi dalam penelitian ini adalah seluruh pasien geriatri gagal jantung yang dirawat inap di rumah sakit Betha Medika, yang berusia lebih dari 60 tahun (pasien usia lanjut) [7]. Sampel dari penelitian ini adalah pasien geriatri gagal jantung yang dirawat inap di rumah sakit Betha Medika, yang berusia lebih dari 60 tahun, dengan penyakit penyerta, dan mendapat lebih dari 2 macam obat yang digunakan bersamaan. Kejadian interaksi obat dievaluasi berdasarkan literatur dari obat yang berpotensi mengalami interaksi dengan keluhan pasien setelah diberikan obat yang diperoleh dari data rekam medik.

\section{HASIL DAN PEMBAHASAN}

Berdasarkan perhitungan jumlah sampel menggunakan rumus Solvin, diperoleh jumlah sampel pasien geriatrik gagal jantung yang dirawat inap selama bulan Maret-April 2016 sebanyak 70 pasien. Prevalensi gagal jantung pada penelitian ini terjadi pada $45 \%$ laki laki dan $54 \%$ perempuan. Pasien perempuan lebih banyak karena pada usia 60 tahun ke atas sudah mengalami menopause dengan resiko menderita penyakit kardiovaskuler yang sama dengan laki-laki. Berbagai penelitian menunjukkan bahwa perempuan produktif atau premenopause mempunyai resiko penyakit jantung lebih rendah dari pada laki-laki.Serangan pertama penyakit jantung pada perempuan umumnya terjadi setelah menopause, atau 8-10 tahun lebih lambat dibanding laki-laki. Perbedaan ini karena peran estrogen yang dapat meningkatkan vasodilatasi, menghambat respon pembuluh darah terhadap cedera dan proses aterosklerosis[8]. 
Sebanyak 10 penyakit penyerta terbanyak yang diderita pasien pada penelitian ini, dapat lihat pada gambar 1 di bawah.
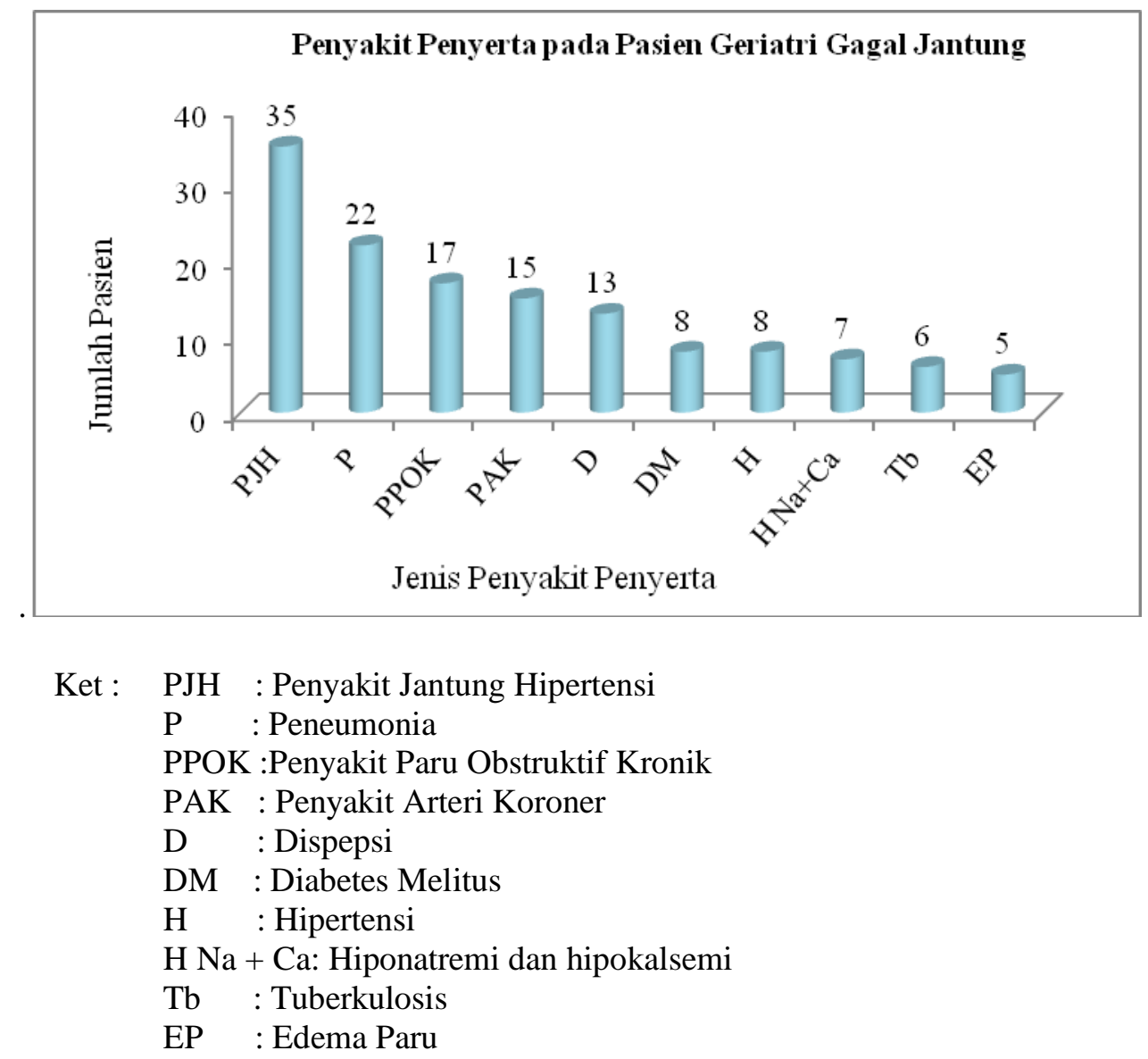

\section{Gambar1. Penyakit Penyerta pada Pasien gagal jantung}

Penyakit Jantung Hipertensi merupakan penyakit penyerta yang paling banyak dialami oleh 35 pasien $(50 \%)$ merupakan komplikasi penyakit jantung. Penyakit Jantung Hipertensi (Hipertensi heart disease (HHD)) adalah istilah yang diterapkan untuk menyebutkan penyakit jantung secara keseluruhan, mulai dari left ventricle hyperthrophy $(\mathrm{LVH})$, aritmia jantung, penyakit jantung koroner, dan penyakit jantung kronis, yang disebabkan karana peningkatan tekanan darah, baik secara langsung maupun tidak langsung [9].

Langkah utama pada pengelolaan pasien dengan gagal jantung kronis secara garis besar adalah penurunan beban kerja jantung, pembatasan natrium, pembatasan air (jarang diperlukan), pemberian diuretik, pemberian penghambat ACE dan digitalis, pemberian penyakat $\beta$ pada pasien dengan gagal jantung kelas II-III yang stabil dan pemberian vasodilator [10].
Penatalaksanaan pasien selama menjalani perawatan, terdiri dari pemberian larutan infuse, obat-obat yang diberikan dengan rute parenteral dan peroral. Obat yang digunakan yaitu obatobat untuk penyakit gagal jantung ditambah dengan obat-obat untuk mengobati penyakit penyertanya. Obat gagal jantung yang digunakan dalam penelitian ini terdiri dari: diuretik (Furosemid dan Spironolakton)), digitalis (Digoksin), vasodilator penyakat kanal kalsium (Amlodipin).

Interaksi obat yang berpotensi terjadi secara teoritis dari obat gagal jantung dengan golongan obat gagal jantung lain, atau obat gagal jantung dengan obat untuk pengobatan penyakit penyerta yang diberikan pada pasiendalam penelitian ini dapat di lihat pada tabel 1 di bawah. 
Tabel 1. Interaksi Obat Gagal Jantung dengan Obat untuk Penyakit Penyerta

\begin{tabular}{|c|c|c|c|}
\hline No & Obat Gagal Jantung & Obat Lain & Efek Interaksi Obat \\
\hline \multirow{2}{*}{1} & \multirow{2}{*}{ Spironolakton } & Digoksin & Digoksin meningkat \\
\hline & & Aspirin & Spironolakton meningkat \\
\hline \multirow{4}{*}{2} & \multirow{4}{*}{ Digoksin } & Amlodipin & Digoksin meningkat \\
\hline & & PPI & Digoksin meningkat \\
\hline & & Rifampisin & Digoksin menurun \\
\hline & & Sukralfat & Digoksin menurun \\
\hline \multirow{2}{*}{3} & \multirow{2}{*}{ Amlodipin } & Antagonis $\mathrm{H}_{2}$ & Amlodipin meningkat \\
\hline & & AINS & Amlodipin menurun \\
\hline \multirow[t]{2}{*}{4} & \multirow[t]{2}{*}{ Bisoprolol fumarat } & AINS & Bisoprolol menurun \\
\hline & & Amlodipin & Efek sinergis \\
\hline
\end{tabular}

\section{Mekanisme Interaksi Obat}

\section{Spironolakton dengan Digoksin}

Interaksi terjadi pada proses Absorpsi, dimana spironolakton menginduksi transporter membran P-glikoprotein (P-gp).Absorpsi aktif dari dalam lumen saluran pencernaan ke dalam darah terjadi melalui transporter membran $\mathrm{P}$ glikoprotein (P-gp).Peningkatan kemampuan dari spironolakton untuk berikatan pada glikoprotein $\mathrm{P}$ ini menyebabkan glokoprotein yang dapat berikatan dengan digoksin menurun, sehingga digoksin yang absorpsi berkurang.

\section{Spironolakton dengan Aspirin}

Interaksi terjadi pada proses ekskresi, dimana aspirin menurunkan sekresi natrium, sehingga natrium dalam darah meningkat, akibatnya efek spironolakton menurun, tetapi aspirin dalam dosis kecil tidak mempengaruhi. Aspirin juga menghambat sekresi aktif canrenone (metabolit aktif spironolakton), sehingga efek metabolit spironolakton meningkat untuk pemberian dosis berikutnya

\section{Digoksin dengan Amlodipin}

Interaksi terjadi pada proses ekskresi, dimana sekresi aktif dari dalam darah ke lumen tubulus proksimal terjadi melalui transporter membran P-glikoprotein (P-gp). Amlodipin menghambat transporter membran $\mathrm{P}$ glikoprotein (P-gp), sehinggapenghambatan ini menyebabkan digoksin yang diekskresi berkurang. Penurunan ekskresi digoksin menyebabkan kadar digoksin di dalam darah meningkat.

\section{Digoksin dengan PPI}

Interaksi terjadi pada proses ekskresi, dimana amlodipin menghambat transporter membran P-glikoprotein, penghambatan ini menyebabkan digoksin yang diekskresi berkurang, dan terjadi peningkatan kadar digoksin dalam darah.

\section{Digoksin dengan Rifampicin}

Interaksi terjadi pada proses metabolisme, rifampisin merupakan penginduksi enzim Cyp 1A dan 3A, menyebabkan digoksin banyak yang dimetabolisme menghasilkan metabolit yang tidak aktif, sehingga efek dari digoksin menurun.

\section{Digoksin dengan Sukralfat}

Mekanisme kerja sukralfat adalah membentuk kompleks ulser adheren dengan eksudat protein seperti albumin dan fibrinogen pada sisi ulser dan melindunginya dari serangan asam, membentuk barier viskos pada permukaan mukosa di lambung dan duodenum, serta menghambat aktivitas pepsin dan membentuk ikatan garam dengan empedu.Pemberian bersama sukralfat dengan digoksin menyebabkan penurunan absorpsi dari digoksin. Interaksi obat sukralfat dengan digoksin terjadi pada proses absorpsi

\section{Amlodipin dengan Antagonis $\mathrm{H2}$}

Interaksi terjadi pada proses metabolisme dimana cimetidin menghambat metabolisme oksidatif amlodipin oleh hati, sehingga kadar amlodipin meningkat. Interaksi terjadi juga pada proses absorpsi dimana penurunan keasaman lambung akan meningkatkan bioavailabilitas amlodipin.

\section{Amlodipin dengan AINS}

Interaksi terjadi secara farmakodinamika, dimana Anti Inflamasi Non Steroid (AINS) bekerja menghambat pembentukan prostaglandin sehingga menghambat vasodilatasi (terjadi vasokontriksi) dan menghambat menghambat sekresi natrium di ginjal sehingga terjadi retensi urine, kedua efek ini menyebabkan tekanan darah meningkat. Efek dari amlodipin menurunkan tekanan darah tinggi berkurang dengan AINS. 
Penggunaan bersama amlodipin dengan AINS juga berpotensi terjadinya perdarahan karena calcium kanal bloker (amlodipin) mengganggu gerakan ion kalsium melalui membrane sehingga menghambat agregasi platelet, dan AINS melalui penghambatannya terhadap enzim cyclooksigenase menyebabkan pembentukan tromboxan yang berfungsi untuk proses pembekuan darah terhambat.

\section{Bisoprolol dengan AINS}

Interaksi obat terjadi secara farmakodinamika, dimana Anti Inflamasi Non Steroid (AINS) bekerja menghambat enzim cyclooksigenase sehingga pembentukan prostaglandin.Efek dari penghambatan prostaglandin yaitu menghambat vasodilatasi (terjadi vasokontriksi) dan menghambat sekresi natrium di ginjal sehingga terjadi retensi urine, kedua efek ini menyebabkan tekanan darah meningkat. Efek dari bisoprolol untuk menurunkan tekanan darah tinggi berkurang dengan AINS.

\section{Bisoprolol dengan Amlodipin}

Interaksi terjadi

secara

farmakodinamika dengan efek sinergis, dimana bisoprolol bekerja dengan cara memblok reseptor beta adrenergik dengan efek menurunkan kerja jantung. Amlodipin bekerja dengan cara menduduki kanal kalsium yang menyebabkan penurunan kontaktilitas miokardium. Penggunaan bersama kedua obat ini menyebabkan efek yang tidak diinginkan yaitu hipotensi dan bradikardi.

\section{Kejadian Interaksi Obat}

Dari hasil penelitian pasien yang berpotensi mengalami interaksi obat dapat di lihat pada tabel 2 di bawah.

Tabel 2. Interaksi Obat yang Berpotensi pada Pasien

\begin{tabular}{|l|l|l|c|}
\hline No & Obat Gagal Jantung & Obat Lain & Jumlah Pasien \\
\hline \multirow{2}{*}{1} & \multirow{2}{*}{ Spironolakton } & Digoksin & 20 \\
\cline { 3 - 4 } & & Aspirin & 13 \\
\hline \multirow{3}{*}{2} & \multirow{3}{*}{ Digoksin } & Amlodipin & 4 \\
\cline { 3 - 4 } & & PPI & 12 \\
\cline { 3 - 4 } & & Rifampisin & 2 \\
\cline { 3 - 4 } 3 & \multirow{2}{*}{ Amlodipin } & Sukralfat & 7 \\
\hline 4 & \multirow{2}{*}{ Bisoprolol } & Antagonis $\mathrm{H}_{2}$ & 4 \\
\cline { 3 - 4 } & & AINS & 8 \\
\hline
\end{tabular}

Pasien yang mendapat obat dan berpotensi terjadi interaksi dievaluasi kejadian interaksinya dari data rekam medis meliputi hasil pemeriksaan laboratorium dan pengukuran tekanan darah, serta keluhan - keluhan yang berupa reaksi obat yang tidak diinginkan sebagai akibat yang timbul dari adanya interaksi.

Tabel 2. Interaksi Obat yang Terjadi pada Pasien

\begin{tabular}{|c|c|c|c|c|c|}
\hline \multirow[b]{2}{*}{ No } & \multirow[b]{2}{*}{$\begin{array}{l}\text { Obat Gagal } \\
\text { Jantung }\end{array}$} & \multirow[b]{2}{*}{ Obat Lain } & \multicolumn{2}{|c|}{ Jumlah Pasien } & \multirow{2}{*}{$\begin{array}{c}\text { Persentase } \\
\text { Kejadian } \\
\text { Interaksi } \\
\text { Obat }\end{array}$} \\
\hline & & & $\begin{array}{l}\text { Berpotensi Terjadi } \\
\text { Interaksi Obat }\end{array}$ & $\begin{array}{c}\text { Terjadi } \\
\text { Interaksi Obat }\end{array}$ & \\
\hline \multirow{2}{*}{1} & \multirow{2}{*}{ Spironolakton } & Digoksin & 20 & 14 & $70 \%$ \\
\hline & & Aspirin & 13 & 5 & $38 \%$ \\
\hline \multirow{4}{*}{2} & \multirow{4}{*}{ Digoksin } & Amlodipin & 4 & 1 & $25 \%$ \\
\hline & & PPI & 12 & 8 & $66 \%$ \\
\hline & & Rifampisin & 2 & 1 & $50 \%$ \\
\hline & & Sukralfat & 7 & 1 & $14 \%$ \\
\hline \multirow{2}{*}{3} & \multirow{2}{*}{ Amlodipin } & Antagonis $\mathrm{H}_{2}$ & 4 & 1 & $25 \%$ \\
\hline & & AINS & 8 & 5 & $62,5 \%$ \\
\hline \multirow[t]{2}{*}{4} & \multirow[t]{2}{*}{ Bisoprolol } & AINS & 5 & 1 & $20 \%$ \\
\hline & & Amlodipin & 2 & 1 & $50 \%$ \\
\hline
\end{tabular}


Peningkatan efek spironolakton dapat dievaluasi dari hasil pemeriksaan tekanan darah, yang menurun dengan cepat. Sedangkan peningkatan kadar digoksin dapat dievaluasi dari keluhan pasien yang merasa sesak, pusing, jantung berdebar atau mual karena peningkatan efek digoksin dengan efek inotropik positif. Penurunan kadar digoksin dievaluasi dengan keluhan pasien yang merasa lemas. Adanya interaksi dari amlodipin dengan obat lain dan bisoprolol dengan obat lain, dimana terjadi peningkatan dan penurunan kadar amlodipin atau bisoprolol dievaluasi berdasarkan hasil pengukuran tekanan darah pasien yang tidak menentu dan turun naik.

Kejadian interaksi tidak mutlak terjadi karena interaksi dari dua obat, kejadian interaksi bisa saling menutupi karena banyaknya obat yang diberikan dan saling berinteraksi dengan lebih dari dua obat.

\section{SIMPULAN}

Kejadian interaksi terjadi pada semua obat yang berpotensi terjadi interaksi, pada pasien geriatrik penderita gagal jantung yang dirawat inap di rumah sakit Betha Medika periode bulan Maret-April 2016.

\section{DAFTAR PUSTAKA}

[1] Stockley, I.H., 1994, Drug Interactions, University of Nottingham MedicalSchool, Nottingham

[2] Setiawati, 2001, Farmakologi dan Terapi, edisi IV, Bagian FarmakologiFakultas Kedokteran UniversitasIndonesia, Jakarta, h. 800-810.

[3] BNF (British National Formulary) 57 ed 2009 , Published jointly by BMJ Group Tavistock Square, London and RPS Publishing Great Britain 1 Lambeth High Street, London

[4] Tatro.D., Drug Interaction Fact, 6 th Ed, Facts \& Comparison A. Wolter Kluwer Company, 2001, 324

[5] Setiati S, dkk, 2013, Prevalensi geriatric giant dan kualitas hidup pada pasien usia lanjut yang dirawat di Indonesia: penelitian multisenter. In Rizka A (editor).Comprehensive prevention \& management for the elderly: interprofessional geriatric care. Jakarta: Perhimpunan Gerontologi Medik Indonesia; 2013:183

[6] Nolan L, O’Malley K, 1988, Prescribing for the ederly, Part 1 : Sensitivity of the ederly to adverse drug reaction, JAGS; 36 (2):142-9

[7] Undang-undang Republik Indonesia No. 13 tahun 1998, tentang Kesejahteraan Usia Lanjut

[8] Purnomowati,A., 2015, Penyakit Kardiovaskuler pada Perempuan, Tangtangan abad ke-21, Fakultas Kedokteran UI, Jakarta.

[9] Katzung, B. (2001). Farmakologi Dasar Dan Klinis. Jakarta: Salemba Medika

[10] Price, Sylvia A.Wilson, Lorraine M. Patofisiologi: Konsep Klinis Proses-Proses Penyakit, Jakarta:ECG,2005. 